\title{
ROLE-PLAYING MODEL: IS IT EFFECTIVE TO IMPROVE STUDENTS' ACCOUNTING LEARNING MOTIVATION AND LEARNING ACHIEVEMENTS?
}

\author{
Laurentius Saptono $^{1 *}$, Budi Eko Soetjipto ${ }^{2}$, Wahjoedi ${ }^{2}$ Hari Wahyono $^{2}$ \\ ${ }^{1}$ Universitas Sanata Dharma, Indonesia; ${ }^{2}$ Universitas Negeri Malang, Indonesia \\ *e-mail: sapto_pak@usd.ac.id
}

\begin{abstract}
Teachers need to organize learning that is contextual, innovative, and interesting so that students are more motivated to learn and they get better learning outcomes. The research was aimed to examine the effectiveness of role-playing model to improve the twelfth-grade social students' learning motivation and their learning achievements on accounting subject with basic competence of practicing accounting cycles of service companies. The research was conducted with a quasi experiment for 3 public high schools in Sleman Regency. There were 206 total respondents for this research. Research data was gathered by using two methods: tests and questionnaires. Independent sample t-test was used for data analysis techniques. The result of this research showed that t-test for equality of mean of learning motivation was significant (sig. $=.000<\alpha=.05$ ) and learning achievement was also significant (sig. = $.000<\alpha=.05$ ). At the treatment class, students' learning motivation was very high and their learning achievement was high. Thus, it was concluded that the role playing model was effective to improve the twelfth-grade social students' learning motivation and their learning achievements on accounting subject with basic competence of practicing accounting cycles of service companies.
\end{abstract}

\section{Keywords: role-playing model, learning motivation, learning achievements}

\section{MODEL ROLE-PLAYING: EFEKTIFKAH UNTUK MENINGKATKAN MOTIVASI BELAJAR DAN HASIL BELAJAR AKUNTANSI SISWA?}

\begin{abstract}
Abstrak: Guru-guru perlu menyelenggarakan pembelajaran yang bersifat kontekstual, inovatif, dan menarik agar siswa-siswa lebih termotivasi untuk belajar dan mereka memperoleh hasil belajar yang lebih baik. Penelitian ini bertujuan untuk menguji efektivitas model role-playing untuk meningkatkan motivasi belajar dan hasil belajar siswa kelas XII SMA Jurusan IPS pada pembelajaran akuntansi dengan kompetensi dasar mempraktikkan siklus akuntansi perusahaan jasa. Penelitian ini dilakukan dengan teknik quasi-eksperimen (quasi-experiment) pada 3 Sekolah Menengah Atas Negeri di Kabupaten Sleman. Jumlah keseluruhan responden penelitian ini sebanyak 206 siswa. Pengumpulan data penelitian ini dilakukan dengan menggunakan dua metode, yaitu tes dan kuesioner. Teknik analisis data adalah independent sample t-test. Hasil penelitian ini menunjukkan bahwa hasil uji t untuk beda rata-rata motivasi belajar adalah signifikan (sig. $=.000<\alpha=.05$ ) dan prestasi belajar adalah signifikan (sig. $=$ $.000<\alpha=.05$ ). Pada kelas yang mendapatkan perlakuan, motivasi belajar siswa adalah sangat tinggi dan prestasi belajar siswa adalah tinggi. Dengan demikian disimpulkan bahwa model role-playing efektif untuk meningkatkan motivasi belajar dan hasil belajar siswa kelas XII SMA Jurusan IPS pada pembelajaran akuntansi dengan kompetensi dasar mempraktikkan siklus akuntansi perusahaan jasa.
\end{abstract}

\section{Kata Kunci: model role-playing, motivasi belajar, hasil belajar}

\section{INTRODUCTION}

The effectiveness of learning accounting at schools has some determinants. Based on survey conducted by Wygal \& Stout (2015), the determinants of learning effectiveness respectively are: class session learning environment, student focus, preparation and organization, importance of the practice environment, passion and commitment to teaching (as a profession), and the design of the course learning environment. This research finding shows that the role of educators in learning process is considered highly important. Educators or teachers are learning facilitators who escort students to the learning goals (Lie, 2013). As learning facilitators, teachers are required to have the willingness of lifelong learning, to develop innovative attitudes, and 
to have high work ethics for those three are proven giving positive effects towards teachers' professionalism (Syamsuriyanti \& Sukirno, 2018). On the other hand, the finding also shows that less creative and innovative learning at classes needs to be obliviated and shifted to more effective learning.

Accounting learning that has been considered to only recount the standardized materials or the best practices in the real world highly needs to adjust students' learning styles so that they are more motivated to expand and deepen their knowledge infinitely (Warsono, 2010; Black, 2010). Accounting e-module, for instance, is designed by some Accounting teachers as an innovation towards the conventional module. Some research reports that e-module use in learning process give benefits to improve students' knowledge (Kim, Pederson, \& Baldwind, 2011; Wolla, 2017; Sitorus, Siswandari, \& Kristiani, 2019), students-based learning (Lai, 2016), improve students' characters (Sitorus et al., 2019), etc. Besides, teachers keep continually develop active, innovative, and innovative learning methods at class. The research of Istiningrum (2017), for instance, found out that the learning methods such as problem-based learning is able to improve students' self-regulated learning skills. Moreover, the learning method of openended experiential learning cases is also proven improving students' professional judgment ability on making accounting decisions (Istiningrum, 2015).

The role-playing learning model is contextual. In accounting learning, such learning model will be very beneficial to juxtapose students' knowledge to accounting best practices in real business world. They are asked to play a role as an accountant in order to identify an accountant's jobs as well as various interactions to other jobs in a business entity. Therefore, students will not only learn imaginatively, yet they construct the knowledge they have based on the experiences and the surrounding business environments. In role-playing learning model, students are required to act based on scenarios without ruling out any possibilities of students to improvise (Martin \& Hanington, 2012). Creating this learning condition will develop students' creativity, relate the current knowledge and the previous knowledge they have, and carry out social roles in the real life (Vinogradovaa \& Ivanovaa, 2016). In other words, role-playing is a learning method intended for encouraging students' thinking and creativity so that they are able to establish and be trained with new languages or new skills, to create motivation, and to actively engage to the learning process (Brickner \& Etter, 2008).

The regulation of role-playing is usually simple, even sometimes it does not need any other except people in a room. If the role-playing needs equipments, prior simulation training can be done. Meanwhile, if the role-playing is directed to create any creative concepts, thus it needs to apply body storming methods beforehand. Role-playing is arranged in a scenario to picture the general situation for further actions, the unfinished tasks, or the goals to be achieved. The players will act based on their roles, as well as the users and stakeholders who support to create the situations. Some research shows that the implementation of role-playing learning model makes students happier to work in team to solve the problems together (Black, 2010), improves students activeness (Mardiyan, 2012), improves students' learning achievements (Mardiyan, 2012; O'Callaghan, Elson, \& Walker, 2012; Anwar, Soffiatun, \& Marlia, 2018).

Accounting teachers may never realize that what is taught is a part of an interconnected world (van Ments, 1983). As a result, students only see parts and not the whole. Role-playing is a complementary technique to help learning and teaching in the fields of accounting and financial management education (Harris, 1997). Through role-playing, students are expected to understand the context of accounting learning that the work of an accountant is related to jobs in other parts of the organization. Even the task of an accountant in managing an organization's financial data can also include more sophisticated tasks, such as developing, implementing and maintaining financial data bases, as well as establishing and monitoring control procedures. Students' knowledge of the accountant's work will help them understand the actual context of accounting lessons so as to make it easier for students to learn accounting. Previous studies have shown that the use of role-playing in accounting studies can increase students' motivation towards understanding and applying discipline in the context of decision making (Harris, 1997) 
Learning motivation reveals to be an important component in a learning process (Davoudi \& Parpouchi, 2016; Oroujlou \& Vahedi, 2011). Motivation is seen important since it affects students' learning (Li \& Pan, 2009; Thomson, De Bortoli, Nicholas, Hillman, \& Buckley, 2010). Learning motivation is derived from an individual by having strong encouragement for achieving a certain goal (Li \& Pan, 2009). Students' learning effort for achieving the goal is determined by their motivation. Teachers should create a conducive learning through correct learning models and strategies so that students are all motivated to learn. Reid (2009) stated that learning motivation is a success key of learning, based on gained internal abilities which is aligned to instructional purpose. In other words, the improvement of students' learning achievement is started from the improvement of students' learning motivation (Levpuscek \& Zupancic, 2008).

This piece of research is aimed to examine the effectiveness of role-playing model to improve the twelfth-grade social students' learning motivation and their learning achievements on accounting subject with basic competence of practicing accounting cycles of service companies. The role-playing learning model is designed to present the more contextual, innovative, interesting learning process for students so that it helps them to understand accounting more concretely and comprehensively. To examine the effectiveness of the role-playing model in the study conducted by comparing students' motivation and students' achievement in the control class and the class treatment before and after the implementation of role-playing models in learning accounting.

\section{METHODS}

The research was conducted with a quasi experiment at three high school in Sleman Regency, namely: Depok State High School, Ngaglik State High School, and Cangkringan 1 State High School. Those three schools were chosen based on stratified random sampling techniques; schools with categories: high, medium, and low based on the average scores of 2017 national examination for economics subject. Accounting materials is part of economic subjects. Accounting materials being examined in national examination was included in economics examination. Randomly taken from two social classes of twelve-grade in each school, one class was a treatment class while the another one was a control class. Both classes were choses based on its similarities: the teachers, learning sources, students number, students gender proportion, class condition, and learning hours. To determine which class was a treatment class or a control class was done randomly. In the treatment class, the partner teacher organized the accounting learning by role-playing learning model. Meanwhile, in the control class, the partner teacher organized the usual accounting learning like any other days. In the research, the research acted as a research observer.

There were 206 students as research respondents. The data was gathered using two methods: tests and questionnaires. Learning motivation was measured by adapting and modifying MSLQ (Motivated Strategies for Learning Questionnaires) (Pintrich, Smith, Garcia, \& McKeachie, 1993; Lackey, 2013). In this research, MSLQ instruments were summarized into 25 questions. Each question was stated in five Likert scales $(5=$ strongly agree, $4=$ agree, $3=$ neutral, $2=$ disagree, 1 $=$ strongly disagree). Meanwhile, students' learning achievement measurement was done by giving multiple-choice test containing students' whole competences.

Empirical validation result for learning motivation showed that corrected item value correlation total ( $r$ calculate) was bigger that $r$ critical value $=.254$ and Cronbach's Alpha $=$ .926 which means that questionnaires items on learning motivation were valid and had very high reliability value. Validity test was done by considering content and construct aspects. Content and construct validity done based on scientific judgment. The result of reliability tes showed that reliability coefficient (KR-21) in pre-test was .763 and in post-test was .782 . This means both pre-test and post-test had high reliability values. The analysis result on the difficulty level for each pre-test and post-test item showed the index values were between .35 to .61 and .43 to .65 consecutively which were categorized medium. Meanwhile, the analysis result on discriminating power for each pre-test and post-test item showed the index values were between .41 to .60 and .50 to .65 consecutively 
which were categorized good. Furthermore, the analysis result on distracters in pre-test and posttest showed that each alternative answer in each item chosen was minimum 5.4\%. Therefore, each item in pre-test and post-test was a good item.

This piece of research adapted pre-test and post-test of non-equivalent comparison group design by Johnson \& Christensen (2014) by including three treatment classes and three control classes in three different schools. Meanwhile, students' learning motivation data was described by each student's total answer scores from the learning motivation questionnaires. Meanwhile, students' learning achievement data was described by each student's final scores from both tests. The data analysis technique to examine the effectiveness of role-playing learning model on basic competence of practicing accounting cycles of service companies was done by comparing learning motivation and learning achievements between the treatment class and the control class before and after the learning process.

\section{RESULTS AND DISCUSSION Results}

Research data was gathered before and after the learning process. The data gathered before the learning process was aimed to map the learning and decide which class to be the treatment class and the control class at each school. However, the data gathered after the learning process was aimed to investigate the changes and differences of learning motivation and learning achievements in the treatment class and the control class at each school. The following presents the research findings before and after the learning process (Table 1). Generally, the level of students' learning motivation for learning accounting in both classes in each school tended to be low. Meanwhile, students' achievements (pre-test scores) on accounting learning were generally low. Both classes at each school did not show any significant difference on students' learning motivation and students' learning achievements (Table 2). Those prior research findings showed that both classes at each school had the same characteristics. One of both classes at each school was chosen randomly as the treatment class, yet another one was the control class.

Table 1. Descriptive Statistics of Students' Motivation and Students' Achievements

\begin{tabular}{lllllllll}
\hline \multirow{2}{*}{ Variables } & State High School/ & \multirow{2}{*}{$\mathbf{N}$} & \multicolumn{2}{c}{ Actual Range } & \multicolumn{2}{c}{ Mean } & \multicolumn{2}{c}{ Std. Deviation } \\
\cline { 6 - 9 } $\begin{array}{l}\text { Class } \\
\text { Students' }\end{array}$ & Depok & & Before & After & Before & After & Before & After \\
& Control & & & & & & & \\
& Experimental & 34 & $45-61$ & $52-66$ & 53.912 & 58.647 & 3.753 & 3.692 \\
& Ngaglik & & $45-61$ & $60-95$ & 54.235 & 83.176 & 4.236 & 9.989 \\
& Control & 34 & $42-58$ & $51-66$ & 50.853 & 58.471 & 3.799 & 3.910 \\
& Experimental & 34 & $39-55$ & $69-94$ & 48.206 & 80.647 & 4.291 & 7.426 \\
& Cangkringan 1 & & & & & & & \\
Students' & Control & 35 & $39-55$ & $47-62$ & 47.857 & 54.457 & 3.743 & 3.853 \\
achievements & Experimental & 35 & $36-52$ & $66-91$ & 45.200 & 77.629 & 4.227 & 7.187 \\
& Depok & & & & & & & \\
& Control & 34 & $42-77$ & $43-83$ & 54.500 & 65.471 & 8.461 & 8.486 \\
& Experimental & 34 & $41-71$ & $58-98$ & 53.647 & 80.647 & 7.808 & 10.242 \\
& Ngaglik & & & & & & & \\
& Control & 34 & $37-72$ & $49-79$ & 49.500 & 60.235 & 8.461 & 5.700 \\
& Experimental & 34 & $36-61$ & $51-92$ & 48.353 & 74.471 & 7.410 & 10.644 \\
& Cangkringan 1 & & & & & & & \\
& Control & 35 & $35-60$ & $44-76$ & 47.143 & 58.429 & 7.405 & 8.548 \\
& Experimental & 35 & $35-55$ & $50-85$ & 46.429 & 71.143 & 6.251 & 8.496 \\
\hline
\end{tabular}


At the next stage, researcher cooperated with the partner teacher to plan the learning activities for the treatment classes. The series of activity before the learning process were: (1) preparing the design of role-playing learning activities for learning the accounting cycles of service companies in the form of a learning implementation design; 2) preparing learning tools; 3 ) preparing assessment and data gathering instruments; 4) together with the partner teacher, discussing the learning implementation design, grouping the students, giving roles for students in groups, and doing simulations with students chosen by the partner teacher.

During the learning process at class, the activities done by the partner teacher were: a) explaining to students about the basic competences to be achieved in the learning; $b$ ) explaining the description of learning model to be applied: role-playing; c) grouping and arranging students in groups as planned; d) explaining each role to played by the students in their group; e) asking the chosen students for the simulations in front of the class: role-playing an example of a financial transaction settlement; f) drawing conclusion on the learning done and evaluating the role played by the students; g) with students, reflecting the learning activities done. The whole process of learning was organized in 3 meetings (90 minutes for each meeting). Each meeting consisted of 2 rounds ( 2 times of role-playing switches). Therefore, every student in a group took turn to play the different roles: as seller or buyer, financial staff, accounting staff and other roles from outside the company.

After the learning activities were thoroughly done, students learning motivation and their learning achievements can be seen in Table 1. Generally, the students' learning motivation for learning accounting in both classes at each school was different. The average of students' learning motivation and the average improvement of students' motivation in the treatment class were higher than in control class. The average of learning motivation in the treatment class at Depok State High School was 83.176, higher than the average of it in the control class of 58.647 (the average of learning motivation at the initial condition in the treatment class improved higher that the average of it in the control class). The average of learning motivation in the treatment class at Ngaglik State High School was 80.647, higher than the average of it in the control class of 58.471 (the average of learning motivation at the initial condition in the treatment class improved higher that the average of it in the control class). The average of learning motivation in the treatment class at Cangkringan 1 State High School was 77.629, higher than the average of it in the control class of 54.457

Table 2. Independent Samples Test of Students' Motivation and Students' Achievements (Initial Conditions)

\begin{tabular}{|c|c|c|c|c|c|c|c|c|}
\hline \multirow{2}{*}{$\begin{array}{l}\text { State High } \\
\text { School/ } \\
\text { Variables }\end{array}$} & & \multicolumn{3}{|c|}{$\begin{array}{c}\text { Levene's Test for } \\
\text { Equality of Variances }\end{array}$} & \multicolumn{4}{|c|}{ t-test for Equality of Means } \\
\hline & & $\mathbf{F}$ & Sig. & $\mathbf{t}$ & Df & $\begin{array}{c}\text { Sig. } \\
\text { (2-tailed) }\end{array}$ & $\begin{array}{c}\text { Mean } \\
\text { Difference }\end{array}$ & $\begin{array}{l}\text { Std. Error } \\
\text { Difference }\end{array}$ \\
\hline \multicolumn{9}{|l|}{ Depok } \\
\hline $\begin{array}{l}\text { Students' } \\
\text { motivation }\end{array}$ & $\begin{array}{l}\text { Equal var. } \\
\text { assumed }\end{array}$ & .599 & .442 & .333 & 66 & .740 & .323 & .970 \\
\hline $\begin{array}{l}\text { Students' } \\
\text { achievement } \\
\text { Ngaglik }\end{array}$ & $\begin{array}{l}\text { Equal var. } \\
\text { assumed }\end{array}$ & .070 & .793 & .432 & 66 & .667 & .853 & 1.974 \\
\hline $\begin{array}{l}\text { Students' } \\
\text { motivation }\end{array}$ & $\begin{array}{l}\text { Equal var. } \\
\text { assumed }\end{array}$ & .473 & .494 & .693 & 66 & .390 & .647 & .983 \\
\hline $\begin{array}{l}\text { Students' } \\
\text { achievement } \\
\text { Cangkringan } 1\end{array}$ & $\begin{array}{l}\text { Equal var. } \\
\text { assumed }\end{array}$ & .294 & .540 & .595 & 66 & .554 & 1.147 & 1.929 \\
\hline $\begin{array}{l}\text { Students' } \\
\text { motivation }\end{array}$ & $\begin{array}{l}\text { Equal var. } \\
\text { assumed }\end{array}$ & .456 & .502 & .784 & 68 & .371 & .657 & .954 \\
\hline $\begin{array}{l}\text { Students' } \\
\text { achievement }\end{array}$ & $\begin{array}{l}\text { Equal var. } \\
\text { assumed }\end{array}$ & .956 & .332 & .436 & 68 & .664 & .714 & 1.638 \\
\hline
\end{tabular}


Table 3. Independent Samples Test of Students' Motivation and Students' Achievement (Final Conditions)

\begin{tabular}{llccccccc}
\hline & & \multicolumn{3}{c}{$\begin{array}{c}\text { Levene's Test } \\
\text { for Equality of } \\
\text { Variances }\end{array}$} & & \multicolumn{4}{c}{ t-test for Equality of Means } \\
\cline { 2 - 9 } & & $\mathbf{F}$ & Sig. & t & Df & $\begin{array}{c}\text { Sig. } \\
\text { (2-tailed) }\end{array}$ & $\begin{array}{c}\text { Mean } \\
\text { Difference }\end{array}$ & $\begin{array}{c}\text { Std. Error } \\
\text { Difference }\end{array}$ \\
\hline $\begin{array}{l}\text { Students' } \\
\text { motivation }\end{array}$ & $\begin{array}{l}\text { Equal var. } \\
\text { assumed }\end{array}$ & 122.278 & .000 & 29.079 & 204 & .000 & 24.961 & .858 \\
$\begin{array}{l}\text { Students' } \\
\text { achievement }\end{array}$ & $\begin{array}{l}\text { Equal var. } \\
\text { assumed }\end{array}$ & 4.701 & .031 & 21.785 & 204 & .000 & 19.903 & .914 \\
\hline
\end{tabular}

(the average of learning motivation at the initial condition in the treatment class improved higher that the average of it in the control class).

The average of students' learning achievements and the average improvement of students' achievements in the treatment class were higher than in control class. The average of learning achievements in the treatment class at Depok State High School was 80.647, higher than the average of it in the control class of 65.471 (the average of learning achievements at the initial condition in the treatment class improved higher that the average of it in the control class). The average of learning achievements in the treatment class at Ngaglik State High School was 74.471, higher than the average of it in the control class of 60.235 (the average of learning achievements at the initial condition in the treatment class improved higher that the average of it in the control class). The average of learning achievements in the treatment class at Cangkringan 1 State High School was 71.143, higher than the average of it in the control class of 58.429 (the average of learning achievements at the initial condition in the treatment class improved higher that the average of it in the control class).

The data of students' learning motivation and students' learning achievements were distributed normal (asymp. Sig (2-tailed) for students' learning motivation $=.083$; asymp. Sig (2-tailed) for students' learning achievements = .914). The results of variance homogeneity test on students' learning motivation and learning achievement variables in the control class and the treatment class were same or homogeneous (Sig. (2-tailed) for students' learning motivation $=.000$; Sig. (2-tailed) for students' learning achievements). Table 3 shows the different test results on students' learning motivation and learning achievements. The research final conditions showed that there was a difference on the learning motivation between the treatment class students and the control class students (Sig. $(2$-tailed $)=.000)$. In regard to the learning achievements, there were also a difference between the treatment class students and the control class students (Sig. (2-tailed) $=.000$ ). Students' learning motivation and achievements in the treatment classes were higher than in the control classes. Therefore, it could be concluded that role-playing learning model was effective to improve students' learning motivation and achievements of accounting learning on basic competence of practicing accounting cycles of service companies.

\section{Discussion}

The first research finding showed that the role-playing learning model was effective to improve students' learning motivation and achievements of accounting learning on basic competence of practicing accounting cycles of service companies. The result of this research was in line with the previous research conducted by Black (2010); Mardiyan (2012); and O'Callaghan et al. (2012). Accounting learning at schools has been developed dynamically from time to time. In the past, learning was dominated by teacher and it was one-way learning process. Nowadays, the learning has shifted to place students as the learning subjects. The teacher role is primarily as the facilitators in students' learning. The atmosphere of learning in the classroom is no longer expected to foster competitive aspects that tend to encourage the unhealthy win-lose attitudes. Hence, such atmosphere tends to degrade students' attitude 
to help each other (Johnson \& Johnson, 2006; Madrid, Canas, \& Ortega-Medina, 2007). In other words, learning at classroom is directed to the more positive way so that students will actively interact and cooperate with each other to achieve the same learning goals together.

According to Brickner \& Etter (2008), the ideal of accounting learning at classroom is by active learning. Active learning is a pedagogic approach that includes students to actively obtain the knowledge. Active learning is derived from individual or small group activities which relate to the learning processes done by all students in class and by taking turn with interval lead by an instructor, in which students' responses are processed and new information is collected as learning result is being presented (Felder \& Brent, 2009). The advantages of active learning for students are: being more interested to learning materials, improving intrinsic motivation, improving their comprehension due to a decrease in resistance to learning materials, developing their willingness to be lifelong learners, improving communication skills, improving interpersonal relationships, improving problem solving skills, improving critical analysis skills and higher thinking (Brickner \& Etter, 2008).

In accounting learning using role-playing model, students were divided into small groups of four. Grouping was based on students' academic ability by relying on the mean of previous daily test results. Each group consisted of heterogenic abilities so that all groups would be relatively homogenous. It was to encourage students to be more helpful to each other and collaborative in role playing. Based on arranged learning scenario, students would take turn to play roles of a sales/procurement staff, a finance staff, an accounting staff, and a party outside the company in every learning cycle. Therefore, they got real learning experiences from different roles. Each student would proceed, gain information, and understand the implications of the information in the accounting part.

Role-playing is a learning model that requires students to be actively involved to the learning process. If properly done, role-playing model will attract students' interest to study in a more interesting way and make them engage to interactions. Furthermore, this learning model will develop students' skill and abilities, responsibilities and leadership in their own learning, peers learning, and group learning, confidence, and creative problem solving which are all almost impossible developed in traditional learning techniques. The experience to play roles is eventually students' learning motivation (Craciun, 2010).

The application of role-playing for accounting learning is intended for students to have a more concrete description about how an accountant work and cooperate with others in various financial transactions. In other words, role-playing learning model is an experiencebased learning. As an experiential learning, role-playing is in-line pedagogy with the advice from the Commission for Change in Accounting Education (O'Callaghan et al., 2012) as well as is compatible to recent students' learning styles (Hawtrey, 2007). According to Hawtrey (2007), experimental learning is an integration of students' active opportunity and participation in learning. Students have been role-changed from passive listener to active learners (Munoz \& Huser, 2008). Previous studies reveal that experiential learning advantages students more. Specht \& Sandlin (1991), for instance, found that experiential learning results to longer accounting retention. Moreover, Black (2010) stated that students are excited to work in teams to solve the problems together.

The second research finding showed that role-playing learning model has been proven effective to improve accounting learning achievements on basic competence of practicing accounting cycles of service companies. The result of this research was in line with the previous research conducted by Black (2010); Mardiyan (2012); O'Callaghan et al. (2012); and Anwar et al. (2018). Role-playing model in this learning model was intended so that students were able to identify applied accounting in the real life. They played role as an accountant who must be able to understand his responsibilities, to identify how to build interactions between accounting department and other departments, and to react on any accounting information available for him. Nevertheless, students must play roles of people who work in other departments and have interactions with accounting department. Hence, this learning asks students to play roles or characters that they are familiar with in their real lives and to develop the cooperation with their friends in this learning process. They do 
not only learn on how an engineering process of accounting information occurs, but they also indirectly practice how to run the internal control function in a financial management system. Janvrin (2003) and O'Callaghan et al. (2012) findings states that role-playing in accounting learning improves students' effectiveness to run internal control and to master the concept of fraud detection.

However, not all students considered that learning accounting is interesting. It was commonly seen as a difficult subject and became unfavorable for social students. This condition urged Accounting teachers to be more creative and innovative in choosing which learning strategies were suitable with students' characteristics and learning themes. Suitable learning strategy turns out to be the way to improve students' active roles and their learning motivation. If students are motivated, they have stronger willingness to learn, and later they place some higher goals for themselves and put some efforts to study (Li \& Pan, 2009). Learning result is the final effect of students' improved learning motivation. This triggers education researchers to conduct research focusing on how to motivate students more since only motivated students will study and learn.

Theories on achieving goals stated that class environment contributed enough to motivate students to study, be cognitively engaged, obtain more academic competences and academic achievements (Wolters, 2004). It was also seen in Nurwati's finding (2009) revealing that positive peer as well as studentteacher interactions contributed to students' learning achievement through learning motivation. Role-playing model application in accounting learning encouraged the teachers to be more open and willingness to learn, work harder to land the abstract knowledge into more concrete and comprehensive pictures of practical accounting systems, to arrange in detail the possibility of each role to be clear connected and easily applied, to have interpersonal qualities, and to attract students. Learning model was also framed in teams and done cooperatively. Team-based learning made students to learn from mistakes and to improve their knowledge and skills as well as to create new solutions for solving the problems so that methods and performance will be improved (Schippers,
Homan, \& Knippenberg, 2013). This learning condition will clearly create positive class environment to support the learning objectives.

Role-playing makes students interested in and encouraged to actively engage so that they are directed to the more effective learning situations (Holt \& Kysilka, 2006). Students' cooperative interactions in classroom enable them to construct knowledge and empower their ideas (Eggen \& Kauchak, 2007). It is because students need to take actions when facing certain situations that need to be resolved like in the real life (Blatner, 2009). Stronger students cooperative interaction enables them to achieve better compared to other interaction patterns (Slavin, 1995; Williamson \& Rowe, 2002). Role-playing learning also enables students to be freely expressive compared to the traditional learning, to voluntarily ask questions to teacher, to cooperate and to develop their academic skills for achieving more significant and higher test results (Slavin, 1995). In general, the results of this study support the findings of previous studies. The implication of the results of this study is that accounting teachers at senior high school level need to consider role-playing models for accounting learning, specifically the basic competencies of practicing the service company accounting cycle, in order to further enhance student motivation and learning achievement.

\section{CONCLUSION}

Role-playing is an experience-based learning model designed in a certain scenario to achieve learning goals. Students are directed to identify the applied accounting in real world. They take turn to play roles; as an accountant who must completely understand his works and the relation of an accountant's works to other sections or departments, especially organizational activities that have implications to financial aspects. Role-playing learning encourages students to actively participate and cooperate, to excitedly play the roles, to improve their confidence, and to improve students' skills in constructing their knowledge. This research shows that the role-playing learning model for basic competence of practicing accounting cycles in service companies is proven effective to improve the twelfth-grade social high school students' learning motivations and achievements. Researcher suggests that role-playing model can be applied on other accounting learning themes. 


\section{ACKNOWLEDGEMENT}

We thank the partner teachers at Depok State High School, Ngaglik State High School, and Cangkringan 1 State High School. We also thank the Directorate of Research and Community Service and Ministry of Research, Technology and Higher Education for financially accommodating this research in the National Strategic research grant scheme.

\section{REFERENCES}

Anwar, S., Soffiatun, S., \& Marlia, S. (2018). Pengaruh model pembelajaran kooperatif role-playing terhadap hasil belajar mata pelajaran akuntansi kelas $\mathrm{x}$ program keahlian akuntansi di SMK Letris Indonesia 2 tahun ajaran 2016/2017. PEKOBIS Jurnal Pendidikan, Ekonomi dan Bisnis. 1(V), 17-25.http://openjournal. unpam.ac.id/index.php/Pekobis/article/ viewFile/1228/975.

Black, A. (2010). Gen y: Who they are and how they learn. Educational Horizons, 88(2), 92-101.

Blatner A. (2009). Role-playing in education. Retrieved from https://www.blatner.com/ adam/pdntbk/rlplayedu.htm.

Brickner, D. R., \& Etter, E. R. (2008). Strategies for promoting active learning in principles of accounting course. Academy of Educational Leadership Journal, 12(2), 87-93. http://www.alliedacademies.org/ articles/aeljvol12no22008.pdf\#page $=93$.

Craciun, D. (2010). Role-playing as a creative method in science education. Journal of Science and Arts, 1(12), 175-182. https:// www.icstm.ro.

Davoudi, A. H. M., \& Parpaouchi, A. (2016). Relation between team motivation, enjoyment, and cooperation, and learning result in learning area based on teambased learning among students of Tehran university of medical science. Procedia Social and Behavioral Sciences, 230, 184189. doi:10.1016/j.sbspro.2016.09.023.
Eggen, P., \& Kauchak, D. (2007). Educational psychology: Windows on classrooms $\left(7^{\text {th }}\right.$ ed.). Upper Saddle River, NJ: Pearson.

Felder, R. M., \& Brent, R. (2009). Active learning an introduction. ASQ Higher Education Brief, 2(4), 4-9.

Harris, P. J. (1997). A seminar role-play model for hospitality accounting and finance education: Development, implementation and evaluation. International Journal of Hospitality Management, 16(1), 65-77. doi:10.1016/s0278-4319(96)00047-3.

Hawtrey, K. (2007). Using experiential learning techniques. Journal of Economic Education, 38(2), 143-152. doi:10.3200/ JECE.38.2.143-152.

Holt, L. C., \& Kysilka, M. (2006). Instructional patterns: Strategies for maximizing student learning. Thousand Oaks, CA: Sage.

Istiningrum, A. A. (2015). Efektivitas openended experiential learning cases dalam peningkatan pertimbangan profesional. [The effectiveness of open-ended experiential learning cases to improve professional judgment]. Cakrawala Pendidikan, 34(1), 47-57. doi:10.21831/ cp.v1i1.4175.

Istiningrum, A. A. (2017). Peningkatan selfregulated learning skills mahasiswa pada mata kuliah akuntansi pengantar melalui problem-based learning. [Improving students' self-regulated learning skills in the introduction to accounting course through problem-based learning]. Cakrawala Pendidikan, 36(1), 81-90. doi:10.21831/cp.v36i1.11080.

Janvrin, D. (2003). St Patrick Company: Using role play to examine internal control and fraud detection concepts. Journal of Information Systems, 17(2), 17-39. doi:10.2308/jis.2003.17.2.17. 
Johnson, B., \& Christensen, L. (2014). Educational research: Quantitative, qualitative, and mixed approaches ( $3^{\text {rd }}$ ed.).California, CA: SAGE.

Johnson, D., \& Johnson, R. (2006). Learning together and alone: Cooperation, competition, and individualization $\left(8^{\text {th }}\right.$ ed.). Needham Heights, MA: Allyn \& Bacon.

Kim, H. J., Pederson, S., \& Baldwin, M. (2011). Improving user satisfaction via a case-enhanced e-learning environment. Education + Training, 54(3), 204-218. doi:10.1108/00400911211210305.

Lackey, C. (2013). Relationships between motivation, self-efficacy, mindsets, attributions, and learning strategies: An exploratory study (Doctoral Dissertation, Illinois State University). http://ir.library. illinoisstate.edu/etd.

Lai, C. (2016). Integrating e-books into sciences teaching by preservice elementary school teachers. Journal of Educational in Science: Environtment and Health (JESEH), 2(1), 57-66. https://www.jeseh. net/index.php/jeseh/article/view/18.

Levpuscek, M. P., \& Zupancic, M. (2008). Math achievement in early. Journal of Early Adolescence, $X X(\mathrm{X}), 1-30$. doi:10.1177/0272431608324189.

Lie, A. (2013, Februari 27). Kurikulum sebagai kendaraan. [Curriculum as a vehicle]. Kompas, 1. https://nasional.kompas.com/ $\mathrm{read} / 2013 / 02 / 27 / 09425764 /$ kurikulum. sebagai.kendaraan.

Li, P., \& Pan, G. (2009). The relationship between motivation and achievement: A survey of of the study of motivation of English majors in Qingdao Agricultural University. English Language Teaching, 2, 123-128. doi:10.5539/elt.v2n1p123.

Madrid, L., Canas, M., \& Ortega-Medina, M. (2007). Effects of team competition versus team cooperation in classwide peer tutoring. Journal of Educational Research, 100(3), 155-161. doi:10.3200/ JOER.100.3.155-160.

Mardiyan, R. (2012). Peningkatkan keaktifan dan hasil belajar siswa dalam pembelajaran akuntansi materi jurnal penyesuaian pada siswa kelas xi ips 3 SMA Negeri 3 Bukittinggi dengan metode bermain peran (role-playing). [Increasing the activeness and student learning outcomes in learning accounting adjusting journal material in class xi ips 3 students of SMA Negeri 3 Bukittinggi with the role-playing method]. Pakar Pendidikan, 10(2), 151-162.

Martin, B., \& Hanington, B. (2012). Universal methods of design. Beverly, MA: Rockport Publishers.

Munoz, C. \& Huser, A. (2008). Experiential and cooperative learning: Using a situation analysis project in principles of marketing. Journal of Education for Business, 83(4), 214-220. doi:10.3200/JOEB.83.4.214220.

Nurwati, A. (2009). Hubungan antara interaksi sosial siswa dengan prestasi belajar bahasa indonesia siswa madrasah ibtidaiyah se-kabupaten Gorontalo. [The relationship between social interaction of students with Indonesian language learning achievement madrasa ibtidaiyah students throughout Gorontalo district]. Cakrawala Pendidikan, 28(2), 109-118. doi:10.21831/cp.v2i2.311.

O'Callaghan, S., Elson, R. J., \& Walker, J. P. (2012). Using role play as an experiential learning tool to introduce students to auditing. ABD Journal, 4(2), 1-24. https:// www.ship.edu/contentassets/569211b0c 6f243808c3c64f54e816cd2/using-roleplay-as-an-experiential-learning-tool-tointroduce-students-to-auditing.pdf.

Oroujlou, N., \& Vahedi, M. (2011). Motivation, attitude, and language learning. Procedia - Social and Behavioral Sciences, 29(2011), 994-1000. doi:10.1016/j. sbspro.2011.11.333. 
Pintrich, P., Smith, D., Garcia, T., \& McKeachie, W. (1993). Reliability and predictive validity of the motivated strategies for learning questionnaire (MSLQ). Educational and Psychological Measurement, 53(3), 801-813. doi:10.117 7/0013164493053003024.

Reid, G.(2009). Effectivelearning andmotivation - ideas and strategies for independent learning. https://www.drgavinreid.com/ free-resources/motivation-ideas/.

Schippers, M. C., Homan, A. C., \& Knippenberg, D. (2013). To reflect or not to reflect: Prior team performance as a boundary condition of the effects of reflexivity on learning and final team performance. Journal of Organizational Behavior, 34(1), 6-23. doi:10.1002/job.1784

Sitorus, D. S., Siswandari, \& Kristiani. (2019). The effectiveness of accounting e-module integrated with character value to improve students' learning outcomes and honesty. Cakrawala Pendidikan, 38(1), 120-129. doi:10.21831/cp.v38i1.20878.

Slavin, R. (1995). Cooperative learning: Theory, research, and practice ( $2^{\text {nd }}$ ed.). Needham Height, MA: Allyn \& Bacon.

Specht, L. B., \& Sandlin, P. K. (1991). The differential effects of experiential learning activities and traditional lecture classes in accounting. Simulation and Gaming, 22(2), 196-210. doi:10.1177/1046878191222003.

Syamsuriyanti, \& Sukirno. (2018). Faktor determinan profesionalisme guru. [The determinant factor of teacher professionalism]. Jurnal Kependidikan, 2(1), 56-67. doi:10.21831/jk.v2i1.10588.

Thomson, S., De Bortoli, L., Nicholas, M., Hillman, K., \& Buckley, S. (2010). PISA in brief: Highlights from the full Australian report. Melbourne: ACER.
Van Ments, M. (1983) The effective use of role-play: A handbook for teachers and trainers. London: Kogan Page

Vinogradovaa, M., \& Ivanovaa, N. (2016). Pedagogical conditions for role-playing game development in senior preschool age children. Procedia - Social and Behavioral Sciences, 233, 297-301. doi:10.1016/j. sbspro.2016.10.134.

Warsono, S. (2010). Reformasi akuntansi: Membongkar bounded rasionality pengembangan akuntansi. [Accounting reform: Dismantling the bounded rationality of accounting development]. Yogyakarta: Asgard Chapter.

Williamson, V. M., \& Rowe, M. W. (2002). Group problem-solving versus lecture in college-level quantitative analysis: The good, the bad and the ugly. Journal of Chemical Education, 79(9), 1131-1134. doi:10.1021/ed079p1131.

Wolla, S. (2017). Evaluating the effectiveness of an online module for increasing financial literacy. Social Studies Research and Practice, 12(2), 154-167. doi:10.1108/ SSRP-04-2017-0014.

Wolters, C. A. (2004). Advancing achievement goal theory: Using goal structures and goal orientations to predict students'motivation, cognition, and achievement. Journal of Educational Psychology, 96(2), 236-250. doi:10.1037/0022-0663.96.2.236.

Wygal, D. E., \& Stout, D. E. (2015). Shining a light on effective teaching best practices: Survey findings from awardwining accounting educators. Issues in Accounting Education, 30(3), 173-205. doi:10.2308/iace-51038. 